\title{
221. Studies on Haptoglobin. II
}

\section{Immunochemical Properties of Haptoglobin and Antihemoglobin Antibody. II}

\author{
By Takehiko SASAZUKI \\ Department of Clinical Genetics, Institute of Medical Genetics, \\ School of Medicine, Tokyo Medical and Dental University
}

(Comm. by Tanemoto Furuhata, M. J. A., Nov. 12, 1970)

Introduction. Human haptoglobins ( Hp 1-1, Hp 2-1, and Hp 2-2) are known to be able to combine not only with human hemoglobin $\mathrm{A}_{1}$ but also with human hemoglobin $\mathrm{A}_{2}$, human hemoglobin $\mathrm{F}$, and other many mammalian hemoglobins. ${ }^{1,2)}$ With deoxygenated human hemoglobin $\mathrm{A}_{1}$, however, human haptoglobin cannot combine. ${ }^{3)}$ In this communication, specificity of binding ability of human haptoglobin and antihuman hemoglobin antibody to various hemoglobins was reported.

Materials and methods. Human hemoglobin $\mathrm{A}_{2}$ was prepared from the human adult hemolysate by the same procedures as has been employed in the purification of hemoglobin $\mathrm{A}_{1}{ }^{4}$ ) The first hemoglobin fraction eluted from DEAE-Sephadex A-50 column in the starting buffer system was used for examination as purified hemoglobin $\mathrm{A}_{2}$. Human hemoglobin $\mathrm{F}$ was prepared by the method of Allen $e t a l .5) \quad$ Hemolysates of horse and rabbit were prepared by the method of Drabkin, ${ }^{6}$ and hemolysates of frog and hagfish were prepared by freezing and thawing, and they were used as hemoglobin solutions. Human haptoglobin 2-1 and hemoglobin-haptoglobin 2-1 complex were purified by the method of Hamaguchi ${ }^{7)}$ with some modification in column size.

Combining ability of human haptoglobin with hemoglobins of frog and hagfish was tested by poly acrylamide gel electrophoresis ${ }^{8), 9)}$ of the mixtures of human haptoglobin and hemoglobins of frog or hagfish, and new benzidine positive bands other than free hemoglobins were judged as the formation of hemoglobin-haptoglobin complex. Antihuman hemoglobin antibody was prepared as described previously. ${ }_{4}^{4)}$ Precipitation reactions of antihuman hemoglobin antibody with various hemoglobins were tested by Ouchterlony double immuno-diffusion technique. ${ }^{10)}$ Combining ability of antihemoglobin antibody with various hemoglobins was also tested as the soluble antigen antibody complex by the disc electrophoresis of the mixture of antihemoglobin antibody and hemoglobin, and new benzidine posi- 
tive band other than free hemoglobin was judged as the hemoglobin antihemoglobin antibody complex. In the case of deoxygenated hemoglobin $\mathrm{A}_{1}$, Wyman's tonometer ${ }^{11)}$ (Fig. 1) which was filled with $\mathrm{N}_{2}$ gas was used for observation of immunological precipitation reaction. Antihemoglobin antibody (C) and hemoglobin $A_{1}(B)$, to both of which the solution of sodium hydrosulfite was added previously, were poured into the cuvette (A), to observe the immunological reaction (Fig. 1).

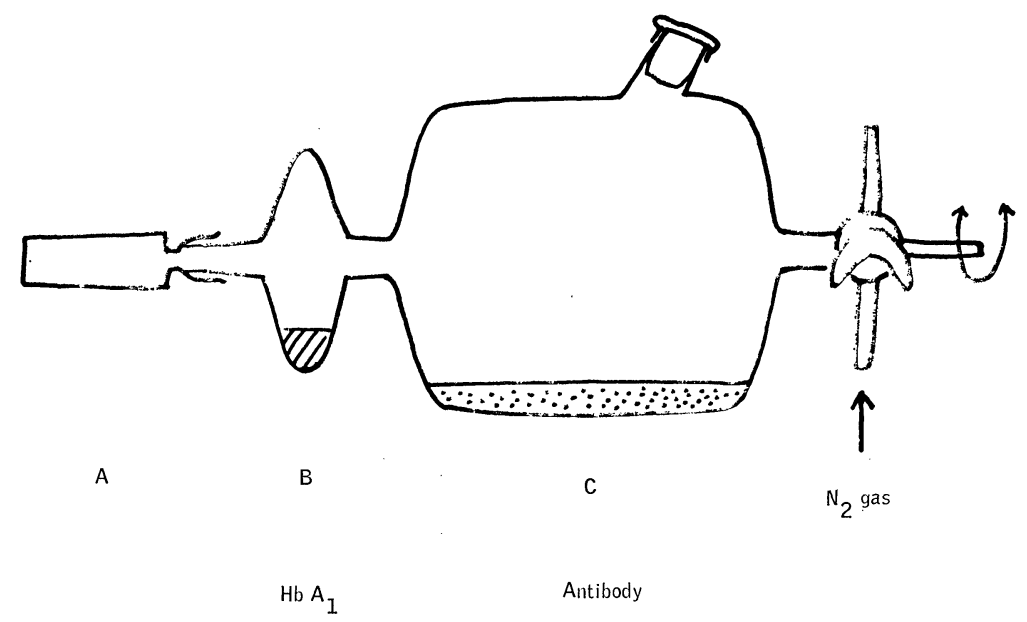

Fig. 1. Precipitation reaction of antihemoglobin antibody with deoxygenated

$\mathrm{Hb} \mathrm{A}_{1}$ in Wyman's tonometer with some modifications.

Results and discussion. As summarized in Table I, specific antihemoglobin antibody can combine and precipitate not only with hemoglobin $A_{1}$ but also with hemoglobin $A_{2}$ and hemoglobin $F$, both having $\alpha$ chains in common with hemoglobin $\mathrm{A}_{1}$. Antihemoglobin antibody

Table I. Combining abilities of antihuman hemoglobin antibody and human haptoglobin 2-1 with various hemoglobins

\begin{tabular}{|c|c|c|c|}
\hline Hemoglobin & Characteristic structure & $\begin{array}{c}\text { Human } \\
\text { haptoglobin } \\
2-1\end{array}$ & $\begin{array}{l}\text { Antihemoglobin } \\
\text { antibody }\end{array}$ \\
\hline Human $A_{1}$ & $\begin{array}{l}0 \text { (Number of amino acid } \\
\text { substitution }\end{array}$ & + & + \\
\hline Human $\mathbf{A}_{2}$ & $10 \times 2(" \prime)$ & + & + \\
\hline Human $F$ & $39 \times 2(\prime \prime)$ & t & + \\
\hline $\begin{array}{l}\text { Human deoxy- } \\
\text { genated } \mathrm{A}_{1}\end{array}$ & $7 \AA$ displacement of $\beta$ chains & - & . \\
\hline Human $\mathrm{Hb}-\mathrm{Hp}$ & Dissociation to $\alpha \beta$ dimer & - & . \\
\hline Horse & & + & \\
\hline Rabbit & & + & \\
\hline Frog & & t. & \\
\hline Hagfish & & - & \\
\hline
\end{tabular}


can also combine and precipitate with deoxyhemoglobin $A_{1}$, which has a $7 \AA$ displacement of the $\beta$ chains compared with the position of these chains in oxyhemoglobin $\mathrm{A}_{1},{ }^{12)}$ and hemoglobin-haptoglobin complex, whereas haptoglobin combines neither of these substances. ${ }^{13)}{ }^{14}$ ) Both human haptoglobin and antihuman hemoglobin antibody cannot combine with hemoglobins of hagfish. From these facts and the observation that haptoglobin does not interfere with the immunological reaction of antihemoglobin antibody with hemoglobin, it is inferred that the binding sites and the binding mechanism of antihemoglobin antibody with hemoglobin seem to differ from those of haptoglobin with hemoglobin.

Summary. Combining ability of antihuman hemoglobin antibody and human haptoglobin with various hemoglobins was tested. Antihuman hemoglobin antibody can combine and precipitate with deoxygenated hemoglobin $\mathrm{A}_{1}$ and hemoglobin-haptoglobin complex with both of which human haptoglobin cannot combine. On the other hand, antihuman hemoglobin antibody cannot combine with hemoglobins of other species with which human haptoglobin can combine. From these observations it is suggested that binding site and mechanisms of antihuman hemoglobin antibody with hemoglobin differ from those of human haptoglobin with hemoglobin.

Acknowledgement. The author is deeply indebted to Professor Hiroshi Nakajima for his valuable advices and criticism throughout the course of this work.

\section{References}

1) M. F. Jayle and J. Moretti: Prog. Hematol., 3, 343 (1962).

2) R. L. Nagel and H. M. Ranney: Science, 144, 1014 (1964).

3) R. L. Nagel and M. C. Rothman, T. B. Bradley Jr., and H. M. Ranney: J. Biol. Chem., 240, PC 4543 (1965).

4) T. Sasazuki: Proc. Japan Acad., 46, 820 (1970).

5) D. W. Allen, W. A. Schroeder, and J. Balog: J. Am. Chem. Soc., 80, 1628 (1958).

6) D. L. Drabkin: J. Biol. Chem., 146, 703 (1946).

7) H. Hamaguchi: Amer. J. Human Genet., 21, 440 (1969).

8) B. J. Davis: Ann. New York Acad. Sci., 121, Art 2, 404 (1964).

9) L. A. Ornstein: Ann. New York Acad. Sci., 121, Art 2, 321 (1964).

10) W. C. Boyd: Fundamentals of Immunology, ed. 3. Interscience Publishers Inc., p. 678 (1956). New York.

11) D. W. Allen and J. Wyman: J. Biol. Chem., 187, 393 (1950).

12) H. Muirhead and M. F. Perutz: Nature, 199, 633 (1962).

13) H. Hamaguchi and T. Sasazuki: Proc. Japan Acad., 43, 332 (1967).

14) R. L. Nagel, M. C. Rothman, T. B. Bradley, Jr., and H. M. Ranney: J. Biol. Chem., 240, PC 454 (1965). 